\title{
Are We Saving Enough? Households and Retirement
}

Doug Campbell and John A. Weinberg

$\mathrm{O}$ n October 15 of last year, a retired school teacher from Earleville, Maryland, sat down at a computer terminal and typed responses to four "yes" or "no" questions, beginning with, "Are you at least 61 years and 9 months old?" In answering affirmatively, Kathleen Casey-Kirschling made history. Born one second after midnight New Year's Day, 1946, she was the first of the 78-millionmember baby boom generation to apply for Social Security benefits. She became eligible to collect with the turn of 2008 .

The reason Casey-Kirschling's otherwise everyday act made news is no mystery. In part because there are so many baby boomers relative to the overall population, Social Security payments to retirees are projected to exceed payroll tax revenues in less than 10 years. By 2041, benefits will have to decline, or taxes or government borrowing will have to increase. In the case of Medicare, the health care insurance system for the American elderly, similar changes are expected to be necessary as early as 2019 .

The baby boom generation's retirement brings into focus perhaps the most significant demographic shift in United States history. Baby boomers, the moniker for the generation born between 1946 and 1964, comprise about 26 percent of the overall U.S. population. Their sheer numbers assure that future growth in the labor force will slow by comparison to recent decades. The birth rate seems unlikely to ever spike up to that experienced in the 1950s, and life expectancy continues to increase.

In 1940, people who had already reached the age of 65 were expected to live to be 77.7 years. By 2030, life expectancy for 65-year-olds

The views expressed are the authors' and not necessarily those of the Federal Re- serve System.

DOI: http://doi.org/10.21144/eq1010202 
is projected to reach 83.7 years. At the same time, birth rates are falling: In 1955 - the core of the baby boom - the average woman had 3.5 children in her lifetime; by 2005, the birth rate had leveled off to about 2 children per woman, a trend that is projected to hold steady for the next 25 years.

These trends signify long-term ramifications for the economic wellbeing of American households. First, the big picture: Population aging presents a problem of consumption maintenance. If a growing number of older people move into retirement, then there are fewer people working as a share of the population, increasing the so-called dependency ratio shown in the first figure in this article. So on a per-person basis, there would be relatively fewer goods and services being produced. The upshot is that people could have less to consume than in the absence of population aging. This statement requires the economist's usual "other-things-being-equal" qualification, which means that other factors in the economy affect economic output per person. Most importantly, productivity growth resulting from technical change or improved work force skills increases output per worker. But regardless of the status of such other factors, an aging population probably means lower average consumption-per-person than would otherwise be possible.

Second, beyond the sustainability of national consumption, population aging threatens the sustainability of the nation's entitlement programs. Social Security and Medicare are pay-as-you-go programs, meaning younger generations of workers finance the retirements of older generations. For Social Security, the present value of benefits promised to older cohorts is $\$ 13.6$ trillion greater than the present value of scheduled tax contributions to the system, according to the Treasury Department. As large numbers of baby boomers retire, they will drain those promised benefits to the point where incoming tax revenue will no longer be sufficient to keep the programs solvent. A similar issue exists at the state and local levels, where many public-employee pension and retiree health care plans are less than fully funded. The growth of public-sector obligations to retiring boomers could strain government budgets at many levels.

Strains on entitlements are only one type of challenge facing today's workers. Employees also are adjusting to the predominance of a relatively new form of retirement saving - defined-contribution pensions, most commonly in the form of employer-sponsored 401(k) plans, in which workers are the main suppliers to their retirement plans. Under such a plan, a household could potentially outlive its savings, unless it was effectively annuitized.

Fading away are defined-benefit pensions, which provide guaranteed income streams for retirees that they can't outlive. At precisely the 
Figure 1 Longer Lives, Greater Dependency

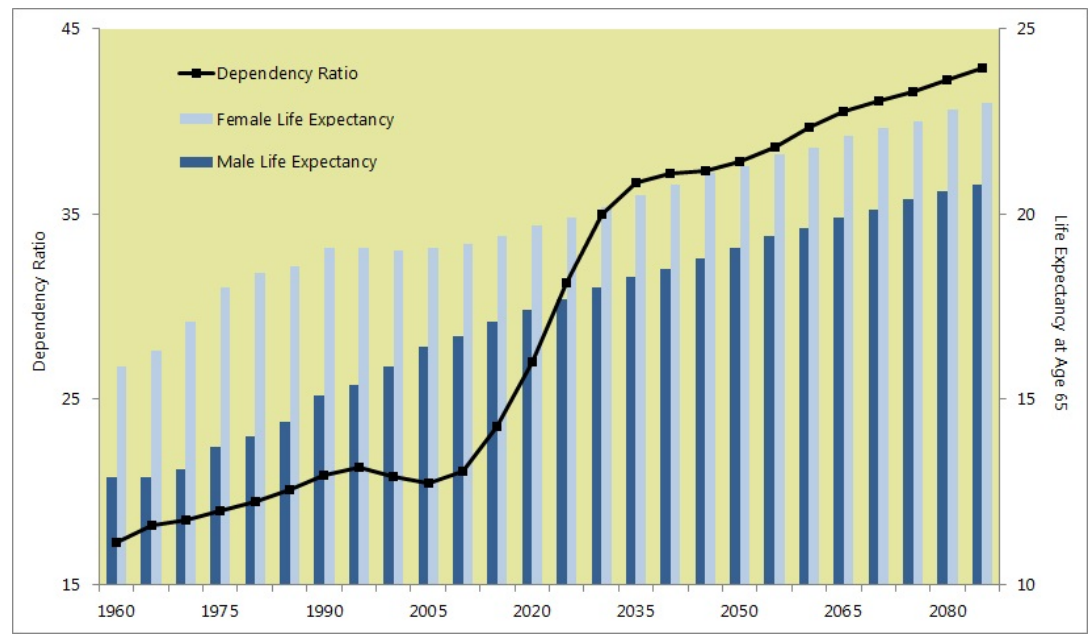

Source: Annual Report of the Social Security and Medicare Boards of Trustees for 2007.

Notes: *Dependency Ratio per 100 workers; Population aged 65 and over, divided by population aged $20-64 ; * *$ Life expectancy at age 65 .

time at which public transfer backstops that mitigate the problem of longer lifespans are in trouble, responsibility for saving is being placed upon the shoulders of individuals, as is the investment risk.

Despite the heightened importance of individual preparedness for retirement, a puzzling observation is that Americans seem to be saving less than ever. The personal saving rate, for example, has been declining. And there is no shortage of anecdotes about overboard consumer spending and people entering their 60s with no nest eggs.

All of this adds up to quite a laundry list of concerns. To review, we have an aging population, which means problems in maintaining national consumption as well as maintaining entitlement programs like Social Security and Medicare. Then we have the tricky transition from guaranteed defined-benefit pensions to employee-driven, definedcontribution $401(\mathrm{k})$ plans. And finally we have economic statistics that appear to show that Americans are saving at historically low rates. We are left with a big question: Are U.S. households going to be financially prepared for retirement?

In this essay, we initially aim to clear up some misconceptions about Americans' saving habits. We look at the data on demographics, 
pensions, and wealth, seeking to identify which trends merit concern and action, and which may not.

Our emphasis is on households. Why households? In the popular media, the cited statistics are almost always aggregate - they consider the state of things across the board rather than by household. The popular press reports endless stories about perilously low saving rates; the implication is that "the economy" is in trouble. But our interest isn't in the aggregate economy but in the economic well-being of individual households - people, couples, and families. In fact, when you look at the data on individual households - that is, disaggregated dataa surprisingly different picture emerges. Most households near retirement are saving adequately. Crucially, insofar as future policies are concerned, their saving is as modern economic theory predicts: They are mostly doing the best they can given their incomes.

Then we consider the future. The finding that households are now saving optimally assumes that the government will deliver on promised Social Security and Medicare benefits. But the demographic shift will stress the federal budget, imperiling those benefits. In addition, we face the related problem that the demographic shift may reduce the size of the overall pie that households can consume (relative to a world in which no demographic change occurs). It might seem wise to find a way to spread these burdens across generations so that future generations don't take the biggest hit. Those ways might include saving more, taxing more, or borrowing more. We will explore the effects of these different approaches, with particular attention to their unintended effects. Understanding the economic tradeoffs inherent in each of these strategies may help us choose well.

\section{MEASURING SAVINGS}

It goes without saying that saving is important. Taking income from present consumption and moving it to savings allows us to finance spending on both physical and human capital to increase the future standard of living. The growth of future living standards depends on how much income is set aside for savings, as well as growth in productivity.

Concern about Americans' readiness for retirement generally can be traced to a single source - the personal saving rate. The most widely cited measure of personal saving comes from the U.S. government's National Income and Products Accounts (NIPA). Boiled down, the NIPA measure is disposable - or after-tax - income minus spending.

This measure held mostly steady between 7 percent and 10 percent of disposable income from the 1950s through the early 1980s. It then 
Figure 2 Personal Saving Rate

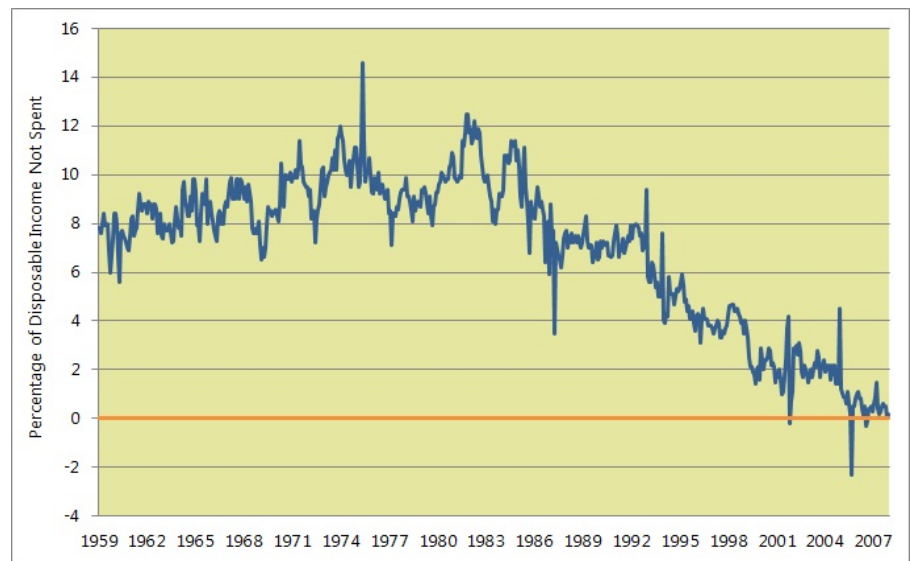

Source: U.S. Department of Commerce.

began to fall, going south of 7 percent in 1990, to 4 percent in 1996, and 2.3 percent in 2001. In 2005, it went into negative territory. In 2006, Americans saved an average of 0.4 percent of their disposable income, and the saving rate has hovered around zero since then. It is impossible to ignore the sharp downward movement that this rate has displayed over the past two decades, and it has fallen more sharply than in most other developed countries.

Why have savings trended so far south? Many assume the main problem is self-control, or lack thereof. People may spend to satisfy immediate needs or cravings, ignoring reality or hoping against all evidence that the future will bring more wealth. A related story is that credit has become easy to obtain, leading households to take on more debt - or at least saving less because they know they can borrow in an emergency.

The components of the NIPA saving rate are worth a closer look. C. Alan Garner, an economist with the Federal Reserve Bank of Kansas City, points out several potential shortcomings. The NIPA rate computes how much household income is put aside for other uses, such as investments in homes or businesses. But it excludes capital gains and losses on existing assets. Therefore, it doesn't include potential changes in wealth from assets ranging from stocks to home equity.

The 1990s and early 2000s saw significant increases in both stocks and housing values. Perhaps households, feeling wealthier, were 
motivated to spend more. Indeed, some economists believe that there is a "wealth effect" on consumption; when household wealth rises or falls, consumption will go in the same direction.

Measured savings is a consequence of households' consumption decisions and shows the difference between measured income and the resulting consumption. Consumption can grow with no corresponding increase in measured income, which drives the saving rate lower but this could be because actual income increased more rapidly than measured income. Meanwhile, those examining the NIPA rate don't have the same perspective as consumers, whose confidence in their future earnings or wealth isn't directly observed. To observers, it may look like some households are saving too little; for some of those households, it may just be a case of spending now in anticipation of higher income later.

For data on household wealth, the Federal Reserve's Flow of Funds Accounts provides some aggregate figures. Overall, wealth has gone up almost every year (it dropped in the 2001 recession), though the growth has slowed in recent decades. It may seem surprising that the saving rate has gone down while net household wealth has gone up. But the two are not historically connected, as wealth changes are a product mostly of changes in stock and real estate asset prices, which are not taken into account by the standard measures of saving. By itself, the NIPA rate doesn't tell us whether Americans are likely to reach retirement with sufficient wealth.

As with all national economic indicators, later revisions can change initial results. Historically, the NIPA saving rate has mostly been revised upward, and sometimes by large amounts. Leonard Nakamura and Tom Stark, economists with the Federal Reserve Bank of Philadelphia, find that initial estimates of personal savings from 1965 to 1999 on average were revised upward by 2.8 percentage points. For the fourth quarter of 1981, for example, the revision was up 7.3 percentage points. Nakamura and Stark attribute the differences to new methodologies that take into account new sources of household income. New data from Census revisions also may play a role in adjusting estimated business sales, which in turn affect personal consumption expenditures captured in NIPA.

Finally, the saving rate is an aggregate measure. It gives no sense of savings across the population's distribution. How much are low-income households saving compared with high-income households? The NIPA saving rate, as generally cited, does not address this question. 


\section{A CLOSER LOOK AT WEALTH}

Many studies have looked at more robust measures of household wealth. Alicia Munnell and Mauricio Soto, economists at Boston College, analyzed the Health and Retirement Study (HRS), which provides panel data from an initial 1992 sample of 7,600 households aged 51 to 61 . It provides a close-up look at where household savings are located at the cusp of retirement.

Financial planners often rely on replacement rates to gauge whether their clients are saving as much as they should. A replacement rate assesses the amount of spending a retired household's savings can sustain relative to its pre-retirement income. A typical rule of thumb is that a retired household should plan to spend between 75 percent and 85 percent of annual income before retirement, because even though expenditures on things like health care might increase, living expenses generally are lower for old people. Munnell and Soto calculate average income replacement rates for households of adult couples with pensions at 79 percent and those without pensions at 62 percent.

Clearly, households with replacement rates of 62 percent can expect to experience declines in their living standards upon retirement. On the other hand, these couples who lack pensions make up just 25 percent of the sampled population.

Sizing up these figures, Munnell and Soto conclude that: "The majority of households retiring today are in pretty good shape. Regardless of how retirement income and pre-retirement income are defined, households with pensions appear to meet the threshold of adequacy." Importantly, Munnell and Soto found that for the mean of the middle 20 percent of soon-to-retire U.S. households, expected payments from Social Security represent an average of 48 percent of their wealth. Their prediction about the adequacy of household wealth assumes that entitlement programs like Social Security will remain solvent.

Economists at Williams College and the Federal Reserve Board of Governors take the next step by analyzing the HRS data for insights into the distribution of savings across the population. David Love, Paul Smith, and Lucy McNair develop a new measure they term "comprehensive wealth," asking whether U.S. households are "adequately" saving for retirement. The authors take one of the first looks at the 2004 wave of the HRS, which captures the "early baby boomers" born between 1948 and 1953. They begin with financial net worth, which they define as the sum of stocks, checking accounts, and CDs, minus non-vehicle and non-housing debts. Also added are balances from defined-contribution pension plans, typically 401(k)s, and IRA balances. Moreover they added present values of defined-benefit pensions, 
Social Security, and welfare, plus expected future labor income. And they added employer matches to defined-contribution plans.

Their findings show that, "overall, households hold comprehensive wealth that is several multiples" of the wealth level necessary to sustain consumption at the official poverty line. The median ratio of wealth to the present value of future poverty lines is 3.56 ; the median annuity value of wealth is $\$ 32,000$. (These are, admittedly, not large nest eggs, but since old people consume less than young people, they may well be sufficient. A retirement annuity of $\$ 32,000$ per person represents a 75 percent replacement rate for a worker earning $\$ 42,700$ a year.) Still, about 12 percent of households lack enough comprehensive wealth to bring them over the poverty line, and 9 percent (with ratios between 1.0 and 1.5) are "near" the line. "Not surprisingly," they write, "there is a close correlation between lifetime earnings and the share of households below or near the poverty line."

Put another way, the working poor often don't have enough savings when older to lift them out of poverty in retirement. Poor households in their working years remain poor in their retirement. "Overall, our findings show a generally optimistic view of retirement savings adequacy among current older cohorts, though with a notable pocket of inadequacy concentrated among those with the lowest lifetime earnings." Like Munnell and Soto, these authors find that expected Social Security payments represent a large share of retirement wealth for those at or below the middle of the lifetime earnings distribution.

\section{A THEORY OF SAVING}

The main reason that looking at aggregate statistics on saving can be misleading is founded on two 50-year-old economic theories. In his 1957 book, A Theory of the Consumption Function, Milton Friedman found that current income matters less in consumption than "permanent" income, by which he meant a long-run average of anticipated income. People tended to smooth their consumption throughout their lifetimes based on how much they expected to earn.

Also in 1957, Albert Ando and Franco Modigliani tested the prediction that people's natural inclination is to smooth their consumption over their lifetimes. When younger and earning less income, people may borrow more and save less. During middle age, when labor income is typically at its peak, people will ratchet up their saving. In retirement, as income diminishes, people spend off their savings. Overall, households estimate the stream of resources over their lifetimes and use that as their benchmark in deciding how much to spend at any given period. 
It turns out that these theories, known as the permanent income and life-cycle hypotheses, have matched up with the data fairly well over time. One of the more recent studies on this front comes from John Karl Scholz, Ananth Seshadri, and Surachai Khitatrakun. What was most unique about their study was that it gained access to previously unavailable Social Security earnings data, providing more precise measures of actual earnings and lifetime income than previously available. They developed optimal decision rules for consumption for each household in the sample, with rules that differed depending on household characteristics, and then plotted the distribution of optimal net worth across households in the HRS.

It should be noted here that the "optimality" of saving as examined by Scholz, Seshadri, and Khitatrakun is related to a specific theory of household behavior. While this theory is the standard approach of economists studying saving and consumption, it necessarily abstracts from many forces that might affect behavior. Still, this idea of optimality is a useful notion that builds on the idea of "adequacy" by taking into account the most important economic factors affecting household choices. Their two most important findings:

- More than 80 percent of households in the observed HRS sample have accumulated wealth above the targets implied by the model, while 15.6 percent of surveyed households with a member nearing retirement age fell short of wealth targets. But the authors note that most of the people who are undersaving aren't undersaving by much.

- At the same time, they find that "undersavers are concentrated in the bottom half of the lifetime earnings distributions." In the lowest earnings decile (basically, people whose incomes are at or below the poverty level), 30.4 percent of households are below the optimal target; in the highest decile, 5.4 percent are below. (The authors caution, however, that this result may be more strongly related to whether a person is in a single or married household.)

What's important about the Scholz, Seshadri, and Khitatrakun model is that it confirms the theoretical notion that households tend to save the amount necessary to provide the maximum level of smoothed consumption over their expected lifetimes. The model takes into account that each household experiences different fluctuations in earnings and life expectancy. Though it may sound odd, viewed through this lens, seemingly paltry levels of wealth may actually be quite consistent with reasonably effective saving behavior, given a household's income experience. At the aggregate level, it is impossible to identify this household-level activity. 
Figure 3 Optimal Savings

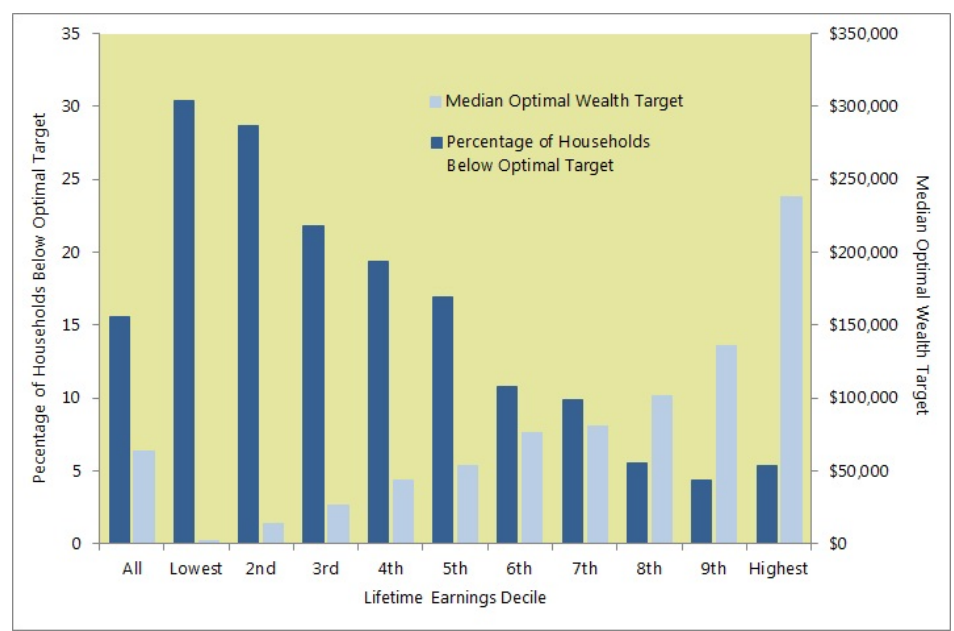

Source: Scholz, Seshadri, and Khitatrakun.

According to these economists and their high-quality data, most people are doing precisely what economic theory says they should be doing. Most people are doing the best they can given their situations. (In fact, one of the authors' main findings is that many people seem to be oversaving.) Most households save enough to generate the highest level of smoothed consumption over their expected lifetimes. As with Love, Smith, and McNair, these authors find that undersavers are also the poorest, suggesting once again that America faces less of a retirement savings problem than a poverty problem.

A downside to the optimality approach, some economists counter, is that what's "optimal" may still make a household "wealth poor" at retirement. It might be the case that for one household, whose wage earners lose jobs or get sick, entering retirement with only Social Security as a backstop is "optimal," as it provides the smoothest possible consumption over their lifetime. But some may consider relying on Social Security alone - with average monthly payments around $\$ 1,000$ a month at present - as simply inadequate. Of course, optimality should not be confused with desirability. Morally or ethically, we might be predisposed to wanting people to have more resources at retirement. Additionally, models that generate optimal consumption paths rely on assumptions that may not be correct, including mortality and risk preferences. 
Having acknowledged these challenges, we can still agree that lifecycle theory seems to be generally squaring with the facts. Given the resources that people acquire throughout their lifetimes, most are arranging for their nonworking years in retirement as best as they can. Addressing poverty - where evidence of undersaving is greatest - is in many ways a different problem.

\section{DEMOGRAPHIC CHANGE}

The judgment that most Americans are saving reasonably well does not mean we should be sanguine about the future. As the disaggregated data show, Social Security accounts for a significant portion of expected retirement income for many households. But the aging of the U.S. population will put strains on the ability of the government to make good on its promised Social Security payments. On top of that, the demographic shift could mean lower economic output and consumption than in the absence of population aging.

We now face choices about how to prepare for these changes and to make good on our promises to workers. Will we have to raise taxes on current or future workers? Many analysts have postulated that higher household saving rates are desirable because they could help ease the burden of higher taxes or lower spending that might otherwise be passed to future generations. To properly evaluate the choices, let's first consider the size of the shift and what it might seem to imply about future consumption possibilities.

When we talk about population aging, it is important to take into account both the larger share of old people and the smaller share of children, because they can have opposite effects on overall consumption levels (with old people consuming more because of their medical needs, and children, less). The declining birth rate means a lowered dependency burden, which ordinarily would be a good thing with regards to per capita consumption. But in this case, it is swamped by the growing number of old people per worker.

At face value, what these trends mean is that younger generations of workers will support larger numbers of old people. Equally, it means there could be fewer goods and services to go around compared with a world in which there is no demographic change. This result is because, in general, consumption per person depends on output per person. So while productivity growth raises output per person, a growing share of retirees in the population holds down those gains on a per-person basis.

To get a clearer understanding of the implications of population aging on consumption, consider the ratio of working-age people (ages 20 to 64 ) to elderly people (older than 65). Currently, there are five 
working-age adults for every person aged 65 and above. By 2030, there will be three working-age adults for every elderly person. Overall, annual growth in the size of the labor force is expected to slow from 1 percent at present to 0.2 percent after 2020. (Obviously, these figures could change if, for example, more people stay in the labor force past the usual retirement age of 65 . Immigration of young workers could also pick up some of the slack.)

Louise Sheiner, Daniel Sichel, and Lawrence Slifman, economists with the Federal Reserve Board of Governors, argue that the best gauge of the macroeconomic effects of population aging is what they call a "weighted support ratio." This takes into account both the heightened consumption needs of the elderly (primarily because of their greater demand for health care) and the lower needs of children. Their weighted support ratio is peaking now at about 0.64 (workers to old people and children, with these populations' consumption needs weighted) as most baby boomers remain in the work force. But it is projected to drop sharply over the next decade, to 0.60 in 2020 , then to 0.56 in 2040. That seemingly small decline actually represents major changes in growth of the U.S. labor force; it means the number of workers to dependent population will be much lower than we've recently experienced, as well as lower than the previous low point in the early 1960s. The weighted support ratio falls farther than the simple support ratio, implying a larger impact on the economy.

Now, it is a bit more complicated than that. A society's potential level of consumption depends, among other things, on capital per worker, technical advancement, and the return to capital. Given current trends, Sheiner, Sichel, and Slifman conclude that we will experience a significant reduction in per capita consumption relative to a baseline in which there is no demographic change. (These trends include assumptions about labor force participation among the elderly and levels of immigration.) This is because the population bulge has made our production bulge as well. We have, in short, experienced a period of low dependency during which per capita output was high. With fertility low relative to that of the baby boom generation, we received a temporary benefit in the form of greater consumption available per person.

\section{WHAT NOW?}

The data presented earlier on household-level wealth holdings suggest that older baby boomers are reasonably well-prepared for retirement. On the other hand, dependency ratio calculations like those presented in the previous section imply a real economic cost of the demographic 
bulge that will weigh on the consumption opportunities of future retirees, future workers, or both. How do we square these two facts? A key assumption in the calculations of household wealth is that future Social Security payments will be made according to current policy. This assumption is important, since for many low- and moderate-income households, expected Social Security payments represent a large fraction of retirement wealth. But as we discuss elsewhere, current Social Security payment policy, together with current taxation policy, creates large fiscal deficits. These will ultimately require changes either in payments or in taxes (or both) and will ultimately affect some people's consumption patterns.

People's responses to the aggregate economic changes brought on by the demographic trends will depend on the prices households face in making consumption decisions and the returns households receive on their labor time and savings. By prices, we mostly refer to wages and interest rates. Does population aging somehow affect prices in such a way that individual households are hindered in their ability to prepare for retirement? We now explain both how population aging could affect prices and then how it doesn't have to.

Intuitively, the most obvious and simple plan might seem to be to save our way out of demographic change - to put more money aside now while we've got more people working. This would require people to consume less, of course, but it would also help lower the burden on future generations. With extra savings, we could add to the capital stock and thus make future workers more productive.

If only it were as simple as that. The effect of increasing the capital stock may actually discourage saving. Federal Reserve Board economists Douglas W. Elmendorf (now with the Brookings Institution) and Sheiner assume that current consumption and saving rates are close to optimal (an assumption supported by other research cited in this essay) to isolate the impact of population aging. They point out that forcing greater saving on current workers is not an obviously beneficial approach to the looming demographic trends.

Here is why: Recall that the U.S. workforce is growing more slowly now with the aging of the baby boomers. With fewer workers, we require less in the way of investment to provide new workers with capital. So if we are trying to save our way out of uneven consumption, we increase the future capital-to-labor ratio (because we have less labor and more capital than before). This means returns on capital are smaller than before, and investment payoffs are lower.

This is not to argue that we should simply kick the burden of demographic change and supporting entitlement programs to future 
generations. Rather, it is to explain the possible complications of that approach. In fact, it's fair to say that all approaches are imperfect.

A study by economists Laurence Kotlikoff, Kent Smetters, and Jan Walliser considered how the combination of demographic change and the burden of Social Security might play out. They conclude that payroll taxes would have to jump by 77 percent, and that this increased tax burden would swamp the extra capital to workers that ordinarily would accompany an aging society. Alternatively, there is the research of Nobel Prize-winning economist Edward C. Prescott and Arizona State University's Kathryn Birkeland: They argue that addressing the solvency of entitlement programs while maintaining the overall welfare of the U.S. population is as simple as having the government issue more debt. Prescott and Birkeland's point is that in the existing tax-andtransfer system, households may pare back their labor in the face of high taxes. Despite the risks, issuing more government debt along with a mandatory worker "saving-for-retirement system" would mean that workers' productive time is rewarded with a larger savings nest egg. This results in a larger capital stock awaiting future generations.

By no means is this an endorsement of any of these approaches. Our aim is to briefly point out what sort of consequences we can expect with each one. You can ask households to save more, but doing so would tend to lower everybody's rates of return. While there are many other ways that economists approach the retirement/entitlement problem amid demographic change, the most useful are those that model households as rational, forward-looking units that respond to incentives. If households face a pricing environment where saving makes sense, they will do so.

While understanding the tradeoffs involved with preparing for demographic change is important, it is also important to take action as soon as possible. In their study, Sheiner, Sichel, and Slifman conclude that if we made no changes to our saving habits, future generations would see their per capita consumption fall 14 percent compared with what it would have been without demographic change. By contrast, if we alter saving rates now as a means to spread the burden equally across generations, the relative decline in per capita consumption is reduced to just 4 percent. While there is always uncertainty around such projections, the desirability of a timely response to demographic change is clear enough.

\section{CHANGES AHEAD}

As the first retiring baby boomer, Kathleen Casey-Kirschling became a symbol for America's demographic transition. Her arrival on Social 
Security's doorstep made long lingering questions more urgent: Do retirees have enough savings? Will her cohorts bankrupt our entitlement programs? Will the sheer size of her generation cause living standards to decline in the future?

We have shown that, contrary to popular opinion, most Americans near retirement are saving largely as economic theory predicts they should. Most of the nation's undersavers are also the poorest. While lack of savings isn't exclusively a problem of the poor, that's where the problem is largest. Our chief concern should be for those who are poor even before retirement.

The aging of the U.S. population is not a surprise. It is a predictable event that we can plan for. Research on household saving behavior shows that most households plan reasonably well. But the important caveat in this conclusion is that household planning appears to be predicated on the assumption that Social Security and other retirement benefits will be paid according to current policy. The fiscal stresses that these policies face imply difficult choices. Increasing taxes to prop up entitlement programs would create additional problems. Should the government take on more debt? Some economists believe that approach is not as unwise as it first sounds - it could ease the burden on current workers while allowing interest rates to remain high enough to encourage household saving.

As we have described, an older society portends a time when the growth of consumption per person might be held down, and saving might become harder. The somewhat natural lengthening of time that older workers stay in the labor force may cushion the demographic blow, as might increased immigration. But in general, whichever approach we take, our focus should be on making sure that households both today and tomorrow are not impaired in their ability to save. If there is no consensus about what to do next, there is agreement that to delay action will exacerbate the problem for future generations. The earlier we embark on this effort, the more likely we are to achieve a desirable outcome.

\section{APPENDIX}

The following sections appeared as sidebars in the original text. 


\section{WHY AREN'T (SOME) PEOPLE SAVING MORE?}

Though careful studies show that many people are saving enough, it's also clear that some people aren't. Why not?

The first possible explanation is that figuring out how much to save is complicated. Economic theory holds that people seek to smooth consumption over their lifetimes. But in the 21st century, this is not such an easy calculation. Annamaria Lusardi and Olivia Mitchell explain the difficulty this way: "The consumer must understand present discounted values, the difference between nominal and real amounts, and be able to project expected future labor income, pensions and Social Security benefits, retirement ages, and survival probabilities, among many other factors. These requirements are inherently complex and demanding."

Within the "it's complicated" explanation fall several subcategories. Some people, for example, may use simple rules of thumb in planning for retirement. These rules might include aiming for certain replacement rates of income upon reaching retirement. But because of the complex nature of investment decisions, this sort of planning may still fall short, and retirees may have to shift down their consumption to adjust. (Some economists dispute the notion that consumers have to understand every detail to properly save for retirement. These economists argue that most people make estimates that turn out to be accurate.)

A related explanation is that people may believe themselves to be financially sophisticated when they really aren't. However, some recent research by Lusardi and Mitchell discounts this notion, finding that most people who classify themselves as financially literate indeed score well on related testing.

A branch of economics is interested in the idea that undersaving reflects a lack of self-control. Some surveys have shown that households themselves cite "lack of willpower" for their low savings, while others admit to procrastination. Behavioral economists use these examples in support of their theories of why people deviate from standard economic rules.

Though much of this kind of work is open to question, recent behavioral research on participation in $401(\mathrm{k})$ plans is striking. The research has shown that if employers make "opt in" the default choice for such plans, more people automatically end up saving than if "opt out" is the default. This evidence runs contrary to traditional theory, which holds that people ought to be making the same decision whether it is the default or not.

Many studies point to a graver problem than the misperception that most people aren't saving enough - it's that undersaving is most

widespread among the poor. A possible explanation is that because 
they have less to gain, poor people invest less in financial planning that would help them save more. They may also face disincentives to saving because of financial backstops like Social Security and welfare transfers. Like a lot of research on savings, this finding points to the need for raising wealth for those with low incomes as much as for increasing their savings.

\section{THE EFFECTIVENESS OF FINANCIAL EDUCATION PROGRAMS}

Of all the ways to encourage higher saving rates, perhaps none is more popular than financial education. If only Americans were made aware of the importance of retirement planning - and given some pointers on how to get started - then changes in savings behavior would surely follow.

That's the conventional wisdom, at least. But despite the seemingly obvious link between knowledge and behavior, economists have struggled to measure the degree to which financial literacy efforts actually work. It is well documented that some people have a poor grasp of basic economic concepts, and that shortfalls of knowledge are particularly evident about Social Security and pensions. But the connection between the effect of being exposed to financial education and subsequent improvements in saving habits is tenuous.

The trick is distinguishing between causation and correlation. There are definite correlations between wealth and retirement planning. Among baby boomers who reported that they undertook even "a little" retirement planning, wealth holdings were twice as large as non-planners, according to economists Annamaria Lusardi and Olivia Mitchell. Meanwhile, many studies have documented that households that do little financial planning tend to be the less educated and minorities. But does that mean that planning can lift these households into more secure retirements?

Lusardi and Mitchell, who are two of the world's leading researchers on the topic, created a "financial literacy index" based on a survey of Americans in their prime working years, with most respondents between 40 and 60, as well as the Health and Retirement Study. With the index, the economists identify which traits and concepts are predictive of retirement planning. In general, they conclude that "financial literacy is a key determinant of retirement planning" and that literacy is highest among those exposed to economics in school and to those who attended company-sponsored programs.

This supports some of their earlier research, which considered the possibility that wealthier households planned more because they had 
more to gain. They couldn't find any effect of wealth on planning, however, and concluded that planning is more likely to cause wealth, rather than vice-versa.

"Saving for retirement is becoming a more and more challenging and a more important objective requiring ever-greater levels of financial sophistication," Lusardi and Mitchell wrote. "Clearly it is urgent to target effective programs to those who can put this necessary financial knowledge to work."

As it happens, the most effective programs do not come cheap. In a survey of the literature on financial education, Richmond Fed economist Matthew Martin concludes that there are returns from such programs, especially to low-income and lesser-educated households. However, Martin finds that one-size-fits-all efforts may not succeed: "Financial education programs are most effective when they are tailored to the needs of the recipient and include face-to-face time, either with a counselor or in a classroom setting." As a result, the most effective programs also tend to be the most costly.

\section{DOES THE DECLINE OF DEFINED-BENEFIT PENSIONS SIGNAL TROUBLE FOR AMERICANS' RETIREMENT YEARS?}

Retirement, as we know it today, is a relatively new concept. Back in 1880, eight in 10 men aged 65 and up still worked. When they stopped, it usually was because they were physically unable to carry on. They relied on family for financial support until their deaths. Self-financed retirement was a luxury affordable mainly to the rich.

Over time, workers came to rely on employer-sponsored pensions (plus payments from Social Security, which launched in 1937). The Pennsylvania Railroad Pension is touted as having kicked off the private pension era with its creation in 1900. Its "defined-benefit" formula generally has been followed ever since.

Defined-benefit pensions provide an annuity at retirement that workers can't outlive. Benefits are a function of years of service and highest salary. The assets of defined-benefit pensions are professionally managed and the employer bears most of the investment risk. Employers first started offering defined-benefit pensions in part to help with worker loyalty and to ward off strikes.

Today, defined-contribution plans, predominantly $401(\mathrm{k}) \mathrm{s}$, have replaced defined-benefit plans as the leading form of employer-provided pension. This transition has raised concerns among some observers, in part because defined-contribution pensions place more of the burden of saving, not to mention the portfolio risk, on individuals. Participation 
in such plans is voluntary, meaning some will opt out of them, even if it would not seem to be in their best interest to do so. And smaller firms don't yet en masse offer 401(k) plans, whose big appeal is the matching contributions that employers make.

Given current trends, what will household portfolios look like as they reach retirement? In one study, economists with Williams College and the Federal Reserve Board of Governors point out that though personal retirement accounts (with defined-contribution plans being the leading contributors) are small in size among people nearing retirement, this doesn't necessarily suggest that Americans have inadequate savings. Instead, it is mostly evidence that they are relatively new vehicles for savings.

In the 2004 Health and Retirement Study, less than a third of households aged 75 and older had personal retirement accounts, compared with about half of households aged 62 to 75 and 61 per cent of those between 51 and 61. Despite this transition to defined-contribution coverage, "we do not find evidence of a steep deterioration in retirement adequacy among the younger households in our sample."

Growth in defined-contribution plans is widely evident. In 1985, assets in private defined-benefit pensions almost doubled those in definedcontribution plans - $\$ 814$ billion to $\$ 417$ billion. In 2005 , assets in defined-contribution plans were on top, $\$ 3$ trillion versus $\$ 2.2$ trillion. By 2040, 401(k) assets are projected to grow eightfold from their 2000 level.

By one study, the number of people covered by defined-benefit pensions over the past 20 years fell by about 30 percent, while the number covered only by a $401(\mathrm{k})$ plan grew 300 percent. The number of participants in defined-contribution plans grew from about 19 million in 1980 to more than 52 million in 2004.

Meanwhile, even though growth in 401(k) coverage has slowed in recent years, participation rates are expected to climb well into the future. Among those 60 -year-olds in the 2 nd earnings decile (i.e., people whose earnings put them between the lowest 10th percentile and 20th percentile of the total population), 401(k) participation in 2000 was 23 percent. By 2040, it's expected to increase to 53 percent. It would seem that even for the relatively poor, pension participation will rise. Overall, participation rates at age 60 are expected to be much higher, topping 80 percent, from the 70th earnings percentile on up.

Economists James Poterba, Steven Venti, and David Wise find that the average 65 -year-old in 2040 will have more than $\$ 450,000$ in personal retirement accounts (in 2000 dollars). Of course, there is wide variance in accumulations. Those in the 2nd earnings decile are 


\section{Figure 4 Mean Projected 401(k) Assets for Cohorts Retiring in 2000, 2020, and 2040}

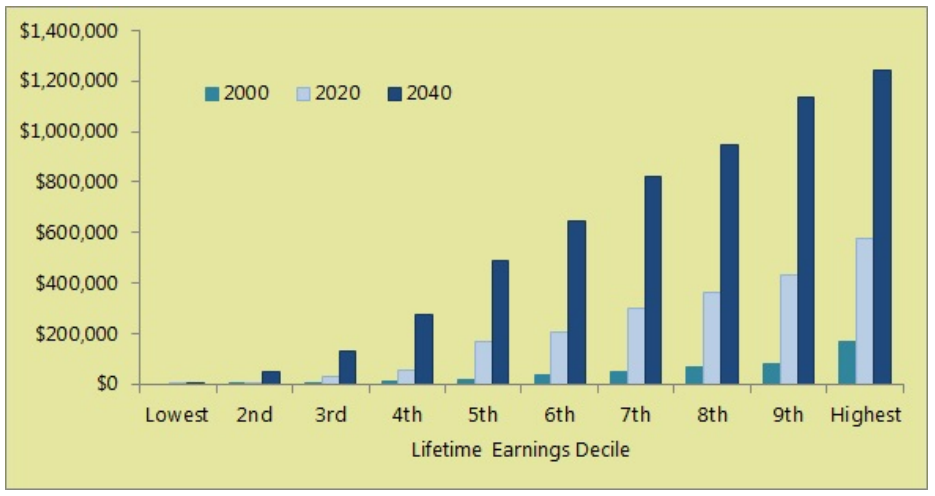

Source: Poterba, Venti, and Wise.

expected to have about $\$ 51,000$ in mean projected $401(\mathrm{k})$ assets; those in the 9th decile (90th percentile and up) about $\$ 1.1$ million.

A lingering concern about $401(\mathrm{k})$ pensions is that so much of their assets are in equities, which tend to be volatile. According to one study, 61 percent of $401(\mathrm{k})$ assets in 2001 were in stocks. But this extra risk has been shown to be offset by the portability of such plans. Employees who take new jobs can take their 401(k) assets with them, but defined-benefit plans effectively penalize workers who leave.

In general, these projections point to future retirement security for most Americans, not the opposite. While the assets of low-income households remain low in retirement, many economists are optimistic that the transition away from defined-benefit pensions is one that ultimately will lead to more wealth for U.S. households: "The advent of personal account saving is projected to yield very large increases in the financial assets of future retirees across the lifetime earnings spectrum," wrote Poterba, Venti, and Wise.

\section{THE FED'S ROLE}

The Federal Reserve's role in the coming demographic transition is several-fold. First, the Fed can encourage households to make sound financial decisions, supporting financial education efforts that inform people about their choices and the importance of saving. In its 
regulation of financial institutions, the Fed ensures that consumers receive adequate disclosures. These roles will be increasingly important as the United States begins its demographic shift.

Most importantly, the Fed abides by its two-part mission - to keep prices stable and promote maximum sustainable economic growth. People decide whether and how much to save based principally on their current and expected lifetime income and interest rates. By keeping inflation low, the Federal Reserve helps keep a stable economic environment. In fighting inflation, the Fed makes it easier for people to save.

\section{NO EASY FIX FOR ENTITLEMENT PROGRAMS}

The financial burden of paying for Social Security and Medicare is growing as the U.S. population ages. That's hardly a revelatory statement, but it bears repeating as the first baby boomers enter retirement and begin to draw benefits from entitlement programs.

Both Social Security and Medicare are essentially "pay-as-you-go" programs, with retiree benefits funded by current payroll taxes levied on employers and employees. The 2007 Treasury Department report calculates that, thanks to population aging, the present value of Social Security's scheduled benefits surpasses the present value of scheduled tax receipts by $\$ 13.6$ trillion - that's the difference between the amount older cohorts put in to the program and the amount they plan to withdraw from it.

Meanwhile, Medicare expenses are expected to overtake income as soon as 2010, with trust fund reserves depleted by 2019. The present value of the unfunded liability for Medicare is close to $\$ 70$ trillion over an infinite horizon. Federal spending to support the two programs is expected to rise from 6 percent of GDP in 2005 to 20 percent in 2080 . Another way to look at it is to focus on the program revenues and outlays as percentages of taxable payroll-income stays relatively flat into the future while expenditures continue to climb.

How do we close these unsustainable financing gaps facing Social Security and Medicare? There is no shortage of proposed reforms. Broadly, they fall into four categories:

- Keep more workers in the labor force, thereby reducing the growth in the number of retired Americans receiving benefits to workers paying taxes that fund those benefits.

- Raise taxes on workers.

- Reduce benefits. 
- Allow greater numbers of young immigrants into the U.S. workforce.

Additionally, there are proposals to phase out the system in favor of private accounts, such as the program that President Bush promoted unsuccessfully in 2005. And there is a school of thought that argues that Social Security should be abolished because its existence has a number of undesirable effects, including that it discourages private savings that might otherwise supplement the program, and that it encourages early exits from the labor force.

So what should be done? One thing that most economists agree upon is that whatever reform is adopted, it will be easier to swallowas well as more evenly spread across generations - if it is taken sooner rather than later. By government estimates, closing the 75-year unfunded liability of Social Security would require an immediate increase in the payroll tax of about 2 percentage points; waiting until 2041 would require approximately a 4-percentage-point boost. Medicare faces a similar scenario - it needs an immediate 3-percentage-point hike to fix the liability, or waiting until 2020 would require a gradual 10percentage-point increase over the following 55 years. But this would still not make the systems permanently solvent; it would merely put them into balance for 75 years.

From a fairness perspective, this observation from the Treasury Department is worth considering: "Each time new legislation has ratcheted up taxes and real benefits, substantial windfalls have been conveyed to individuals in mid-to-late working life at the time of the change, as these individuals face increased taxes for only a relatively few years but are entitled to receive the full advantage of the benefit increases."

The late Edward Gramlich, a former Federal Reserve Board governor, was one of the nation's leading thinkers on the topic of reforming Social Security and Medicare. His proposal consisted of two main parts: First, he would eliminate the now $\$ 102,000$ (but rising slowly each year) cap on wages that are taxable for Social Security, thus bringing in more revenue.

On the benefit side, Gramlich wanted to raise both the early eligibility age and the normal retirement age for Social

Security, and then keep qualifying ages common across both Social Security and Medicare. On balance, the changes would be sufficient to permanently fund Social Security, but would still leave large holes in parts of the Medicare system. And politically, Gramlich conceded, it might be a tough sell. "The package of taxing all payrolls for Social Security and advancing the normal retirement age is indeed strong medicine," he said in a 2005 speech. 


\section{Figure 5 Social Security and Medicare Income and Cost Rates}

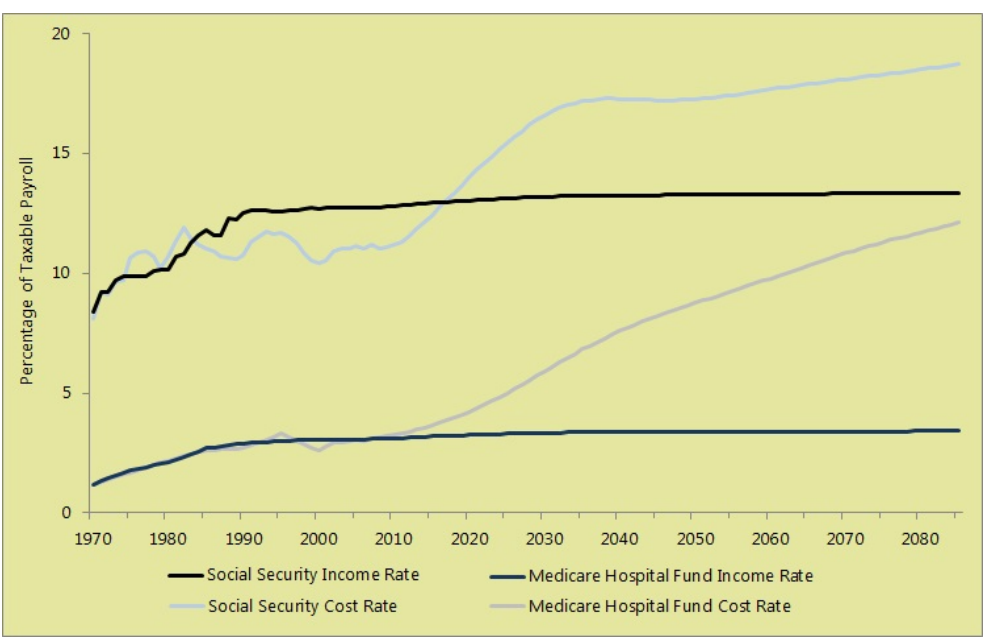

Source: Annual Report of the Social Security and Medicare Boards of Trustees for $200 \%$.

\section{REFERENCES}

Aguiar, Mark, and Erik Hurst. 2005. "Consumption vs. Expenditure." Journal of Political Economy 113 (5): 919-48.

Bernheim, Douglas, Jonathan Skinner, and Steven Weinberg. 2001.

"What Accounts for the Variation in Retirement Wealth Among U.S. Households?" American Economic Review 91 (4): 832-57.

Birkeland, Kathryn, and Edward C. Prescott. 2007. "On the Needed

Quantity of Government Debt." Federal Reserve Bank of Minneapolis Quarterly Review 31 (1): 2-15.

Campbell, John. 2006. "Household Finance." Journal of Finance 61 (4): $1,553-604$.

Elmendorf, Douglas W., and Louise M. Sheiner. 2000. "Should America Save for its Old Age? Fiscal Policy, Population Aging, and National Saving." Journal of Economic Perspectives 14 (3): $57-74$. 
Friedman, Milton. 1957. A Theory of the Consumption Function. (1st ed.) Princeton, N.J.: Princeton University Press.

Garner, C. Alan. 2006. "Should the Decline in the Personal Saving Rate Be a Cause for Concern?" Federal Reserve Bank of Kansas City Economic Review, Second Quarter: 5-27.

Gramlich, Edward. 2005. "A First Step in Dealing with Growing Retirement Costs." Remarks at the Spring 2005 Banking and Finance Lecture, Widener University, Chester, Penn., April 21, 2005.

Gramlich, Edward. 2006. "Another Attempt at Social Security Reform." University of Michigan Retirement Research Center Policy Brief (February).

Kotlikoff, Laurence, Kent Smetters, and Jan Walliser. 2002. "Finding a Way Out of America's Demographic Dilemma." National Bureau of Economic Research Working Paper 8258.

Lettau, Martin, and Sydney Ludvigson. 2004. "Understanding Trend and Cycle in Asset Values: Reevaluating the Wealth Effect on Consumption." American Economic Review 94 (1): 276-300.

Love, David, Paul Smith, and Lucy McNair. 2007. "Do Households Have Enough Wealth for Retirement?" Federal Reserve Board of Governors Finance and Economics Discussion Series 2007-17.

Lusardi, Annamaria, and Olivia S. Mitchell. 2007. "Baby Boomers Retirement Security: The Role of Planning, Financial Literacy, and Housing Wealth." Journal of Monetary Economics 54 (1): 205-24.

Lusardi, Annamaria, and Olivia S. Mitchell. 2007. "Financial Literacy and Retirement Planning: New Evidence from the Rand American Life Panel." University of Michigan Retirement Research Center Working Paper 2007-157.

Martin, Matthew. 2007. "A Literature Review on the Effectiveness of Financial Education." Federal Reserve Bank of Richmond Working Paper 07-03.

Munnell, Alicia H., and Mauricio Soto. 2005. "What Replacement Rates Do Households Actually Experience in Retirement?" Center for Retirement Research at Boston College Working Paper 2005-10.

Nakamura, Leonard, and Tom Stark. 2005. "Benchmark Revisions and the U.S. Personal Saving Rate." Federal Reserve Bank of Philadelphia Working Paper 05-6. 
Poterba, James, Steven Venti, and David A. Wise. 2007. "Rise of 401(k) Plans, Lifetime Earnings, and Wealth Retirement." National Bureau of Economic Research Working Paper 13091.

Poterba, James, Steven Venti, and David A. Wise. 2007. "The Changing Landscape of Pensions in the U.S." National Bureau of Economic Research Working Paper 13381.

Samwick, Andrew, and Jonathan Skinner. 2004. "How Will 401(k) Plans Affect Retirement Income?" American Economic Review 94 (1): 329-43.

Scholz, John Karl, Ananth Seshadri, and Surachai Khitatrakun. 2006. "Are Americans Saving 'Optimally' for Retirement?" Journal of Political Economy 114 (41): 607-43.

Sheiner, Louise, Daniel Sichel, and Lawrence Slifman. 2007. "A Primer on the Macroeconomic Implications of Population Aging." Federal Reserve Board of Governors Finance and Economics Discussion Series 2007-01.

"Social Security Reform: The Nature of the Problem." U.S. Department of the Treasury, Issue Brief No. 1 (undated).

Thaler, Richard H., and Shlomo Benartzi. 2004. "Save More Tomorrow: Using Behavioral Economics to Increase Employee Saving." Journal of Political Economy 112 (1): S164-87.

"The 2007 Annual Report of the Board of Trustees of the Federal Old-Age and Survivors Insurance and Federal Disability Trust Funds." 2007. Social Security Administration, Washington, D.C. 